\title{
Value engineering method in Polish construction
}

\author{
Agnieszka Leśniak ${ }^{1}$, and Marzena Lendo-Siwicka ${ }^{2, *}$ \\ ${ }^{1}$ Cracow University of Technology, Faculty of Civil Engineering, ul. Warszawska 24, 31-155 \\ Kraków, Poland \\ ${ }^{2}$ Warsaw University of Life Science- SGGW, Faculty of Civil and Environmental Engineering, \\ ul. Nowoursynowska 159, 02-776 Warszawa, Poland
}

\begin{abstract}
Value engineering is a method of searching for and eliminating unnecessary costs, while maintaining or even increasing the assumed functionality and quality of the structure, in accordance with the investor's requirements. The paper presents the definition and assumptions of value management in construction projects and presents the results of surveys conducted among Polish engineers. The aim of the research was to show whether Polish engineers and specialists in the field of construction have knowledge about value management and whether they put it into practice.
\end{abstract}

\section{Introduction}

The fundamental objectives of the implementation of construction projects relate to the timely completion [1-4] and the achievement of a specific quality of the building within the assumed budget. During the planning of the construction process, most attention is focused on risk analysis, especially final costs and deadlines of the investment [5]. What is sought is the tool to expand the possibility of making rational investment decisions allowing savings in public and private expenditure. When planning construction projects, costs play a key role. In the literature, various mathematical models can be found supporting the process of reliable cost calculation at the project planning stage $[6,7]$. Value engineering is one of the methods of reducing estimated costs. The objectives of value engineering are dominated by cost reduction [8]. Already at the pre-design stage, its application leads to cost optimization through the use of favorable technical and economic solutions [9]. Value engineering is a method of eliminating unnecessary costs while maintaining or improving the functions of goods, products or services [10]. This method differs from other ways of cost reduction which, by using cheaper substitutes of materials, reduces their quality, which often leads either to the loss of the intended investment standard or to irregularities in the functioning of the building structure. Value engineering meets the expectations of investors who are struggling with the problem of exceeding the planned budget for investment implementation. The aim of the paper is to present the

\footnotetext{
* Corresponding author: alesniak@L3.pk.edu.pl
} 
results of research conducted among the Polish engineering staff regarding knowledge about value engineering and the practical application of this method.

\section{Theoretical approach to value engineering}

The origins of value engineering (VE) date back to the 1960s when the concept first appeared in American literature. Value engineering is an elaboration of a broader term, value analysis method (VA) [11]. In the available literature, L.D. Miles, an employee of General Electric, is considered to be the forerunner of the value analysis. In 1947 he investigated the efficiency of using replacement materials instead of the more expensive ones in manufactured products. Miles criticized the activities of the "rationalizers", who focused their attention exclusively on the tested product, excluding its functions. On the basis of his research and experience, the General Electric employee decided that the reduction of the cost of a given product should be sought in reducing the costs of the functions expected by the user, not in reducing the cost of the product itself [12].

Initially, value analysis was used to rationalize industrial production, but soon this innovative approach began to be used to design, transport, planning, services and organization. This method has been applied in various sectors of the economy of industrialized countries, including construction. The method reached the West European countries at the end of the 1950s. In Poland, this concept was used for the first time in 1966 in the National Rail Carriage Factory in Wrocław. This year marks the beginning of its development [13].

As mentioned earlier, in the 1960s the term "value engineering" was introduced in American literature, referring to the reduction of costs in the initial design phase when the preliminary technical documentation is already prepared and no spectacular cost reduction is possible. Extending the method of value analysis to other branches of the company's activity resulted in the introduction of new concepts, such as "purchase analysis" for purchasing analysis, "value control" to control the costs of business operations, or "value administration" for the analysis of business administration activities. All these methods are based on the same assumptions, the aim of which is the ability to make accurate decisions that allow savings in the company's expenses [12]. In the 1980s, another concept was introduced, namely value management.

Currently, there are three terms used in construction: value analisys, value engineering and value management, often, wrongly [14], used as synonyms. In [10] the authors point out that value management (VM) is the most comprehensive concept containing three components:

- value planning (VP), used during the conceptual phase of the venture;

- value engineering (VE), used during the development phase of the project;

- value reviewing (VR), used at any time in the investment lifecycle to monitor the effectiveness of value management which applies to all activities leading to the improvement of the value of the investment.

Accordingly, value management (VM) is a process which starts at the concept stage and goes through the design, construction, operation and ending stages of the building's life. On the other hand, value engineering (VE) is a narrower concept and applies only to the development phase of the project. It should be noted, therefore, that the above-mentioned terms are not identical and should not be used interchangeably.

The benefits of using the value management methods are the greatest in the early investment phase and decrease with the degree of its advancement (Figure 1). At the design stage, the cost reduction is still quite significant, so it seems right to apply value engineering then. 


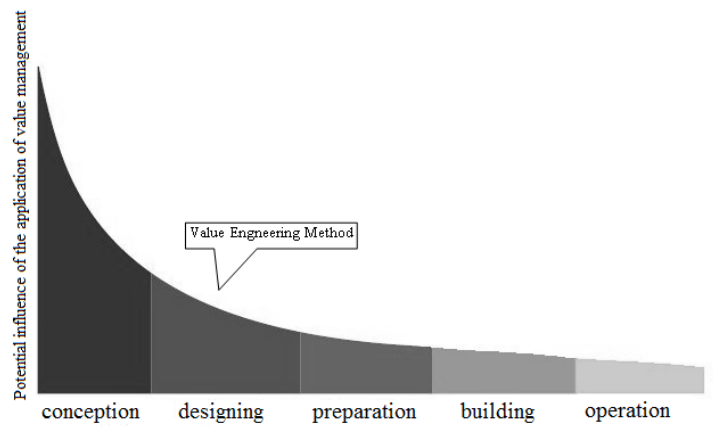

Fig. 1. Potential influence of the application of value management to a construction investment. Source: [15]

Value engineering belongs to the methods of functional analysis, and its basis is the examination of two basic components defining a construction object: function and value. The VE method draws attention not only to individual components but also to the relations between them $[9,12]$. The concepts of functions and values are described below.

Function. Paying attention to the function analysis results from the fact that the clients do not focus on a set of specific product components but on the functions that a given product or object is supposed to fulfil. Thus, they do not concentrate on the composition or the formula of the subject under study. Such an approach is an essential condition for pursuing the goal of value engineering: obtaining a product with a high utility value at a minimum cost. For the purpose of achieving the assumed goal, the research team considers the following issues $[9,10,16]$ :

- what functions should the subject of the study meet to meet the investor's expectations;

- how to get better variants of solutions with smaller outlays, rejecting the previous ones;

- how to guarantee the function is fulfilled at a given price level.

Value. In value engineering, the research team uses the concept of economic value, understood as the lowest cost of meeting particular functions. In the literature on the subject, the following economic values have been distinguished $[9,10]$ :

- usable - properties that ensure usability and fulfilment of the desired function;

- attractive - properties or features that stimulate the desire for possessions;

- exchangeable - properties or features of the product that allow its exchange for something else;

- own cost - the sum of labour, material and general costs necessary to create a given object.

In order to obtain the appropriate value of the product, it is necessary to incur certain expenses, called costs, for its production. It should be noted that the cost of the product may be increased, while its value may not change. The relationship between value, function and cost is presented in the following equation:

$$
\text { value }=\frac{\text { function }}{\text { cost }}
$$

The source of economic effects which result from the application of the value engineering method is undoubtedly the possibility of determining the origin of unnecessary costs in the project under consideration. The awareness of the existence of these costs allows to introduce changes aimed at minimizing them. In other words, VE uses creative thinking techniques which, through the introduced innovations, permit the exaggeration of excessive costs $[13,17]$. 
The application of VE techniques results in lowering costs due to the influence of a variety of factors, the most important of which include [13]:

- elimination of unnecessary and thus redundant functions existing before the analysis of the examined subject;

- application of new, innovative solutions in place of those already existing, with lower cost and higher quality.

In the case of the VE method, one should not speak solely about two basic advantages, namely, cost reduction and increase in quality. It also determines different values. First and foremost, it allows the project to be defined in a transparent and clear manner in relation to the investor's needs, and supports key arrangements by maximizing values. This method is used to generate new, innovative technical solutions and favors stabilization between the initial project and costs occurring throughout the life cycle of a construction project.

There exist many sources through which the VE method is so effective. It can be concluded that the source of the economic effects of the application of value engineering are the following [13]:

- using the analysis of the functions of particular products or of technical solutions;

- the use of creative thinking techniques as opposed to traditions and accepted views that inhibit technological progress;

- $\quad$ organization of the team's intellectual potential for the purpose set;

- application of scientific and technical information, including changes taking place in a material, technological or constructional base;

- application of numerous research methods to obtain optimal solutions.

A research using the VE method is carried out according to a fixed programme of action, ensuring logical correctness of the team's operation. The methodology consists of seven independent stages in which the beginning of each subsequent stage should be preceded by the full completion of the previous stage. This practice is based on the sevenpoint plan of the analysis by L. Miles, who was the first to prepare it for the needs of industry. After the necessary adaptation of the work programme to the needs of the construction industry [14], it can be presented in the form of the diagram shown in Figure 2. Details of individual stages of the research programme can be found in [14].

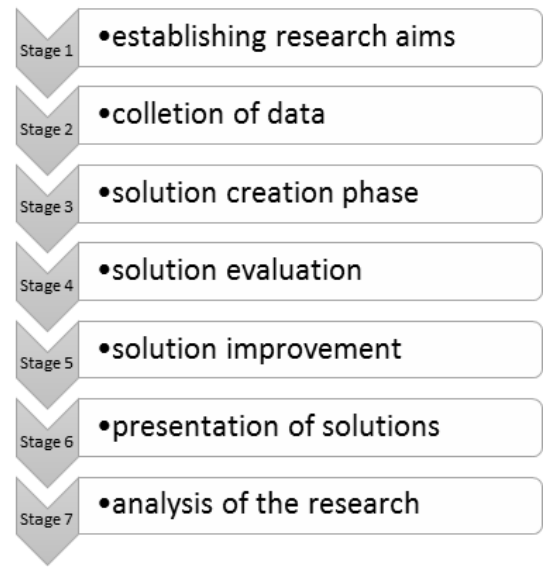

Fig. 2. Diagram of the research programme. Source: based on [14] 


\section{Value engineering in practice in Poland - state of the art}

In February 2018, the authors of the paper conducted pilot studies among engineers operating in Poland. The aim of the research was to establish the degree of knowledge about the issues in the domain of value management among practitioners. To conduct the research, a questionnaire was directly provided to persons participating in the study. Architects, design engineers, contractors' engineers as well as consultants involved in the construction investment process were approached. As a result, 33 completed questionnaires were obtained. The structure of the group of respondents is shown in Figure 3.

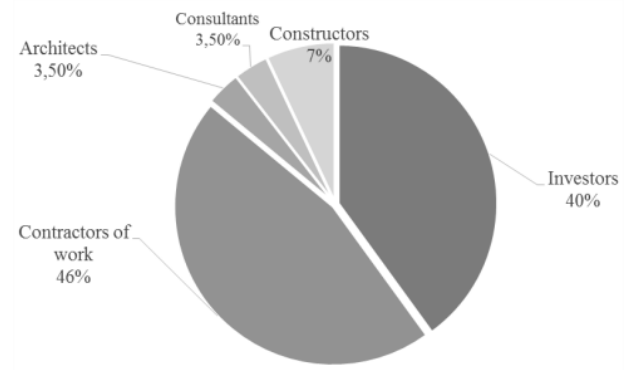

Fig. 3. Structure of the set of research participants. Source:[own study]

Almost half of the surveyed participants were building contractors, followed by investors (40\%), while architects and constructors jointly constituted several per cent.

The first part of the survey included a question: Have you ever heard about value engineering? Nearly half of the respondents (43\%) said they had never heard of the term, and $57 \%$ said they had heard about engineering values. Among those who heard about value engineering only $12.5 \%$ learned the term at work, and as many as $41 \%$ heard about value management during their studies. It is worth noting that in similar surveys carried out in 2010 [15] nearly $60 \%$ learned this method only while working, and only $10 \%$ while studying. $29 \%$ of respondents got acquainted with the VE method using industry magazines. The answers obtained concerning the source of knowledge about value management are presented in Table 1.

Table 1. A summary of the survey responses regarding knowledge about value management.

\begin{tabular}{|c|c|c|c|c|c|}
\hline $\begin{array}{l}\text { Selected survey } \\
\text { questions }\end{array}$ & \multicolumn{5}{|c|}{ Answers } \\
\hline $\begin{array}{c}\text { Have you ever } \\
\text { heard of value } \\
\text { engineering? }\end{array}$ & $\begin{array}{c}\text { Never } \\
43 \%\end{array}$ & $\begin{array}{c}\text { Yes } \\
57 \%\end{array}$ & - & - & - \\
\hline $\begin{array}{c}\text { Source of } \\
\text { information about } \\
\text { value engineering }\end{array}$ & $\begin{array}{c}\text { At work } \\
12 \% \\
\end{array}$ & $\begin{array}{c}\text { Industry } \\
\text { magazines } \\
29 \%\end{array}$ & $\begin{array}{c}\text { When } \\
\text { studying } \\
41 \%\end{array}$ & $\begin{array}{c}\text { From the } \\
\text { Internet } \\
18 \%\end{array}$ & - \\
\hline $\begin{array}{l}\text { The purpose of } \\
\text { applying the value } \\
\text { engineering method }\end{array}$ & $\begin{array}{c}\text { This is } \\
\text { required by } \\
\text { the } \\
\text { cooperators } \\
12.5 \%\end{array}$ & $\begin{array}{l}\text { In order to } \\
\text { reduce the } \\
\text { investment } \\
\text { costs } \\
50 \%\end{array}$ & $\begin{array}{c}\text { In order to } \\
\text { receive a } \\
\text { more } \\
\text { effective } \\
\text { project } \\
25 \%\end{array}$ & $\begin{array}{l}\text { In order to } \\
\text { free the } \\
\text { creative } \\
\text { thinking } \\
0 \%\end{array}$ & $\begin{array}{l}\text { In order to } \\
\text { avoid the } \\
\text { unnecessary } \\
\text { and to obtain } \\
\text { lower unit } \\
\text { costs } \\
12.5 \%\end{array}$ \\
\hline $\begin{array}{c}\text { Have you heard } \\
\text { about the use of } \\
\text { value engineering? }\end{array}$ & $\begin{array}{l}\text { No } \\
60 \%\end{array}$ & $\begin{array}{c}\text { Yes } \\
40 \%\end{array}$ & - & - & - \\
\hline
\end{tabular}

Source: own research 
$40 \%$ of the respondents encountered the practical application of value engineering. Only $36 \%$ say that the value management method is used in their company. Five people perform value analyzes by themselves, in eleven cases it is used in the company in which the respondent works and in five cases the performance of value analysis is outsourced to external companies. The main reason for applying value management is to reduce investment costs, avoid unnecessary costs and ultimately achieve lower unit costs.

The research also involved participants expressing their opinion on value management. The answers obtained are listed in Table 2.

Table 2. A summary of responses regarding value management knowledge.

\begin{tabular}{|c|c|c|c|c|c|}
\hline \multirow{2}{*}{ Question } & \multicolumn{5}{|c|}{ Answers } \\
\cline { 2 - 6 } & Definitely Yes & Yes & I don't know & No & Definitely No \\
\hline $\begin{array}{c}\text { Value engineering consists } \\
\text { mainly in cost reduction }\end{array}$ & $3.40 \%$ & $41.40 \%$ & $48.30 \%$ & $6.90 \%$ & $0.00 \%$ \\
\hline $\begin{array}{c}\text { Value engineering brings } \\
\text { significant benefits }\end{array}$ & $0.00 \%$ & $17.20 \%$ & $75.86 \%$ & $6.90 \%$ & $0.00 \%$ \\
\hline
\end{tabular}

Source: own research

The results indicate that the vast majority of participants in the research cannot provide a concrete answer to the questions asked, which probably results from the lack of thorough knowledge about this issue. As far as the question about the idea is concerned, $40 \%$ of respondents believe that it mainly concerns cost reduction. The vast majority (76\%) cannot answer whether value management brings any significant benefits. A nearly identical percentage of responses (75\%) to this question were obtained in a study from 2010 [15].

\section{Summary and conclusions}

Value engineering differs from standard methods of cost reduction which involve using cheaper materials or abandoning certain devices necessary to achieve the originally intended object standard [15]. When applying value engineering, the elimination of unnecessary costs cannot reduce the assumed functionality or quality of the object. This method focuses on the function that the material or object and not on its cost. In the VM method, it is important to achieve the given function at the lowest possible cost and to maintain the technical parameters, quality, aesthetics and functionality of the output material. The number of supporters of this methods is systematically growing. Both investors and contractors apply VE. This is the optimal way to increase project efficiency and to reduce costs without compromising investment quality. Value engineering uses creative techniques combined with the latest construction technologies. There are two approaches to the application of VE: at the design stage, the selection of the optimal design and/or material solution, as well as the selection of the best alternative at the tender stage.

Surveys conducted among specialists in the field of preparation and implementation of construction investments quoted in the article are not satisfactory despite the developing method of value engineering. The research carried out in 2010 [15] reveals that the level of knowledge about value engineering is still low. On the other hand, it should be noted that nearly half of the respondents start their professional career already possessing knowledge of the EV method, while in 2010 they obtained it only after starting work.

To summarize the paper, its authors draw attention to the great interest of Polish engineers and people involved in the investment process to acquire knowledge in this area and thus to the need to promote it in the form of trainings, seminars, conferences and postgraduate studies. 


\section{References}

1. N. Ibadov, Int. J. Environ. Sci. Technol. (2018)

2. E. Plebankiewicz, M. Juszczyk, J. Malara, Archives of Civil Engineering, 61(3), 0024 (2015)

3. M. Krzemiński, Acta Physica Polonica 130.6 (2016)

4. M. Krzemiński, Archives of Civil Engineering, 63(4), 0037 (2017)

5. M. Lendo-Siwicka, M. Połoński, K. Pawluk, Archives of Civil Engineering, 62(1), 0058 (2016)

6. M. Juszczyk, A. Leśniak, K. Zima, ID: 7952434, Complexity (2018)

7. A. Leśniak, M. Juszczyk, Archives of Civil and Mechanical Engineering, 18(3), 01.014, (2016)

8. S.D. Green, Beyond value engineering: SMART value management for building projects. International Journal of Project Management 12.1, 49-56 (1994)

9. S. Atabay, N. Galipogullar, J. of Traffic and Transportation Engineering, 1 (2013)

10. J. Kelly, S. Male, D. Graham, Value management of construction projects (Blackwell Science Ltd, 2004)

11. S. Qipinig, L. Guiwen, J. of Construction Engineering and Management, 129.5 (2003)

12. W. Biliński, J. Ceraficki, A. Nowakowski, Analiza wartości (Warszawa, PWE, 1972)

13. O. Celejewski, J. Karpińska, S. Król, B. Miłkos, B. Onyszko, Analiza wartości w przemyśle budowlanym (Warszawa, Arkady, 1976)

14. A. Minasowicz, Efektywność i zarządzanie finansami $w$ budownictwie (Warszawa, Poltext, 2009)

15. A. Leśniak, K. Zima, Technical Transaction, 107 (2010)

16. R. Cooper, Target costing and value engineering (Routledge, 2017)

17. M. Sungwoo, H. Chideok, Y. Jinkook, J. of Construction Engineering and Management, 138.7 (2011) 